\title{
The State and Unemployment
}

$\mathrm{T}$ WE report of the Commissioner for the Special Areas in England and Wales for the year ended September $30,1938^{*}$, indicates that the activities of the Department have been devoted to continuing work previously begun and making extended efforts to attract new industries to the areas.

Very satisfactory progress appears to have been made with the trading estates at Team Valley and Treforest, and the Commissioner has also provided factories on other sites, including several which can accommodate many undertakings, such as the Solway Estate, Maryport, and the sites at Pallion, St. Helens, Auckland and Dowlais. Some sites were originally acquired for the clearance of industrial ruins, and at the end of September twenty factories were occupied or in preparation in certain districts outside the estates, where the problem of unemployment has been most intractable, including the Rhondda Valley, Dowlais, south-west Durham and Cleator, west Cumberland. In addition to the powers to provide factories and to offer inducements, the assistance which is available towards capital, either in the form of a loan or by taking up shares or debentures, has been of special value in establishing new industries. For this there are available the Nuffield Trust, the Special Areas Reconstruction Association and the Treasury Fund. The Commissioner considers that the time is too short to draw any final conclusions regarding the value of the provisions of the Special Areas (Amendment) Act, 1937, for the encouragement of now undertakings in the Special Areas, which have now been exercised for sixteen months. Even, however, if some help to the Special Areas is immediately forthcoming as a result of restrictions on the growth of London, he considers it would be a mistake to reduce the powers at present available for encouraging new industrial activity in these areas. They continue to present a serious working problem of a population in excess of the present employment capacity, which cannot be solved by short-term methods.

The report shows that between mid-1936 and mid1937 the population of the Special Areas in England and Wales fell by 42,000 as compared with 38,000 in the preceding twelve months and 23,500 in 1934-5. The total fall in the three years was 3.6 per cent and this fall continues to be due wholly to migration from the Special Areas, although the natural increase in population, due to excess of births over deaths, is still steadily decreasing in rate, having fallen by 43 per cent in seven years, as compared with 25 per cent in the rest of the country. In the Durham and Tyneside Special Area the rate of decrease of population was not so great as in the previous year, but in the other two main Special Areas it was greater.

The Special Areas have been affected by the general trade recession to a slightly less degree than the rest of the country, the percentage of unemployment during the year increasing from $21 \cdot 4$ to $24 \cdot 3$, mainly in South Wales and Durham. Although the increase in the whole of Great Britain was two and one half times as great as in the Special Areas, the percentage

* Report of the Commissioner for the Special Areas in England Pp. vii +120. (London: H.M. Stationery Office, 1938.) 28. net. of unemployment in the latter remains nearly twice as high as it is for the country as a whole- $-24 \cdot 3$ as against 13.6. A striking feature of the present situation is the increase of $\mathbf{3 4}$ per cent in the number of men, aged 18-20 years, unemployed, between May, 1937 and May, 1938 as compared with a decrease of 42 per cent in this group between May, 1936 and May, 1937. This increase is attributed partly to a decline in transference. With regard to the prolonged unemployment which characterizes the Special Areas as compared with the rest of the country, although the position has improved since 1935, the proportion of long-unemployed men remains approximately as it was three years ago, three and one-half times as high as in the rest of the country.

The Commissioner points out that the main difficulty in solving the unemployment problem in the areas has been due to the fact that in the past the areas have been dependent largely on one or two heavy industries, such as coal-mining, iron and steel and shipbuilding. There has been comparatively little variety in the types of employment provided and the demand has been predominantly for male labour. A good deal of the new industrial development has been of the light industry type in which the proportion of female labour is higher, and accordingly it has not had quite the same effect in increasing the employment of men. The development of new industries has, however, also led to the provision of training facilities to assist unemployed persons to obtain work in their own districts in industries new to the locality.

The position of the local government services has also improved and when a number of hospital schemes have been completed, the health services should be substantially up to the level of the services in other parts of the country. Especially in the north-eastern area, progress has been made in clearing away the industrial ruins of past days. In regard to social work, the need for continuing the provision of holidays by the sea for children on the grounds of health is stressed, as well as for school camps and assisting the settlements. Once again special emphasis is laid on the importance of preventing demoralization among the young men, and of bringing them within range of useful occupation and opportunities of ordinary wage-earning employment. The Commissioner considers that the measures available to him under the Special Areas Act and the valuable training and transference facilities afforded by the Ministry of Labour are not wholly adequate to meet the need. In his view it would be reasonable in selected cases to require applications for unemployment assistance, as a condition of the receipt of a cash payment, to attend one of the instructional centres or physical fitness classes organized by the Ministry of Labour. Unless such an applicant could show good cause, he should be confronted with a choice between compliance with a reasonable condition if he is to continue to receive cash payments, and one form of assistance which would contain an element of deterrence. The Commissioner simultaneously, however, stresses the importance of further efforts to devise schemes to provide new 
openings for the able-bodied unemployed, particularly young men.

The Commissioner for the Special Areas in Scotland* also insists on the necessity for a long view. A boom in the heavy industries is little more than a temporary relief, and the object should be to change the unstable industrial equilibrium by introducing as many secondary industries as possible. $\mathrm{He}$ concludes that no solution which aims at getting the older men back into ordinary wage-earning employment can wholly succeed. Despite its inherent difficulty,

* Report of the Commissioner for the Special Areas in Scotland for the period 1st September 1937 to 30th September 1938. (Cmd 5905.) Pp. viii +88 . (London: H.M. Stationery Office, 1938.) 18. $6 d$. net. some form of sub-economic development must be provided. The absence of any serious attempt to co-ordinate the activities of the various social service organizations in Scotland is criticized, and the Com. missioner considers that further expenditure from the Special Areas Fund would be fully justified if it welded into a strong national body the various organizations at present doing fine work in most difficult circumstances. In regard to industrial development, the Commissioner suggests that more might be done to help new and experimental processes, and that a scheme designed to foster new enterprise in the area should include encouragement of such processes, even if in the nature of things their ultimate success was bound to be problematical.

\section{International Congress of Tropical and Sub-Tropical Agriculture}

$\mathrm{T}$ HE eighth International Congress of Tropical and Sub-Tropical Agricul ture was held at Tripoli during March 13-17, under the presidency of Prof. Le Plae, honorary general director of agriculture to the Colonies' Ministry, Belgium, in the unavoidable absence of Prof. Franco Angelini, secretary-general of the International Federation of Technical Agriculturists (F.I.T.A.). Delegates from Italy, France, Belgium, Holland, Poland, Germany, Bulgaria and other countries attended the Congress, and Great Britain was represented by Sir John Russell, as chief Government delegate, and by Sir Arthur Hill.

The Congress was opened by H.E. Marshal Balbo, Governor-General of Libya, who also presided at the concluding meeting. At the opening meeting, papers were presented by Prof. Armando Maugini on "European Colonization and Native Agriculture in Tropical and Sub-Tropical Countries", by Count Edmond de Warren on "Agricultural Production of the Warm Countries" and by Prof. Le Plae on the "Professional Preparation of Native Agriculturists through Compulsory Instruction". The Congress then broke up into five sections. The first dealt with the possibilities of agriculture in tropical and subtropical countries, Sir John Russell being one of the presidents of this section. In the second section papers were read on agricultural problems relating to ecology, meteorology, erosion, irrigation and dry culture; while the third section dealt with various economic problems such as credit, labour, co-operation and marketing.

The fourth section was in two parts, one devoted to vegetable products, of which Sir Arthur Hill was one of the presidents. Numerous papers dealing with cotton, sugar-cane, rubber, olives and vines in North Africa, citrus, etc., were presented, and also papers dealing with forestry. In the other subsection, papers relating to animal products were read.

The fifth section was devoted to insect and fungus pests of cultivated crops.

Visits were paid to the Agricultural and Zootechnical Experiment Station near Tripoli where fine new laboratories have just been completed; the grounds contain a very representative collection of citrus species and varieties, and of vines, almonds and other trees of economic value. The citrus, including grapefruit, were bearing large crops.
Of particular interest were the visits to the new villages of Crispi, Michele Bianchi and Oliveti, which have been recently built. Crispi, only some four months old, is situated in a seemingly desert plain and consists of some 333 farms with a civic centre where the church, town hall with cinema, hospital, school and co-operative store are arranged around a central square. The farms allotted to each colonist are 37-120 acres in extent according to the locality, part being irrigated for the growing of wheat, lucerne, cotton, etc., the rest being dry-farmed with olive and almond trees and vines.

Crispi with its new white houses in this sandy spot was not a prepossessing sight, but a visit to Bianchi and Oliveti, nearly three years old, was a revelation of the possibilities of irrigation and good cultivation, since at the start they were founded on sites as sandy and barren as Crispi.

At these two villages, the olive and almond trees were flourishing and beginning to bear, and the irrigated crops were in very good condition-a great tribute to the good work of the Italian colonists from the Venetian plain and to the foresight of the organizers of these remarkable developments. No doubt in Roman times much of this North African 'desert' country was fertile, else such magnificent cities as Leptis Magna and Sabratha would not have been founded.

The new colonist is provided with his house, sheds and farm on trust, together with the equipment and livestock. After a short time on a fixed salary, he is placed on a crop-sharing basis for about five years and in the sixth year he becomes full owner of the farm and assumes direct management. At the end of nine years, when he has paid one-third of his debt, the colonist becomes full owner of his farm. The whole debt is expected to be paid off before the end of the thirty-fifth year.

This eighth Congress was admirably organized by Dr. Gioacchino Dallari, colonial adviser of the Fascist Confederation of Land Workers, and his staff. The majority of delegates were conveyed from Genoa, Naples or Messina in the S.S. Roma, a fine cruiser of 30,000 tons which served as their headquarters during the Congress.

It was suggested that the Congress in 1941 might be held in England. 